\title{
Poderes do relator em colaboração premiada
}

Supremo Tribunal Federal (STF)

28/06/2017 PLENÁRIO

QUESTÃO DE ORDEM NA PETIÇÃO 7.074 DISTRITO FEDERAL

Voto

\section{O SENHOR MINISTRO CELSO DE MELLO:}

\section{A importância do tema em julgamento}

Quando esta Suprema Corte, em sessão plenária, reuniu-se, em 1971 para apreciar o RHC 48.728/SP interposto pelo líder de uma perigosíssima organização criminosa, o eminente Relator da causa, o saudoso Ministro LUIZ GALLOTTI, antes de examinar o fundo da controvérsia, pôde lançar uma grave advertência sobre o alto significado da decisão a ser então tomada por esta Corte, enfatizando que se tratava, à semelhança do que também ocorre na espécie em análise, de um daqueles casos emblemáticos em que o Supremo Tribunal Federal, ao proferir o seu julgamento, estará, ele próprio, sendo "julgado pela Nação" ( 


\section{O Ministério Público como instituição essencial da República}

Sabemos todos que a persecução penal, cuja instauração é justificada pela suposta prática de um ato criminoso, não se projeta nem se exterioriza como uma manifestação de absolutismo estatal ou de voluntarismo particular.

Importante por isso mesmo, não desconhecer que, com a prática do ilícito penal, consoante acentua a doutrina, "a reação da sociedade não é instintiva, arbitrária e irrefletida; ela é ponderada, regulamentada, essencialmente judiciária" (GASTON STEFANI e GEORGES LEVASSEUR, “Droit Pénal Général et Procédure Penale", tomo II/1, 9a ed., 1975, Paris; JOSÉ FREDERICO MARQUES, "Elementos de Direito Processual Penal", vol. 1/11-13, itens 2/3, Forense), tudo a justificar o ponderado exame preliminar dos elementos de informação cuja presença revele-se capaz de dar consistência e de conferir verossimilhança às investigações $\underline{\mathbf{e}}$ aos atos de persecução criminal em juízo, sob pena de a atuação dos organismos estatais (Polícia Judiciária e Ministério Público) transformar-se em simples exercício burocrático de um poder gravíssimo que foi atribuído ao Estado.

Dentro desse contexto, assume relevo indiscutível o encargo processual que incide sobre o órgão da acusação penal, pois, no âmbito de uma formação social organizada sob a égide do regime democrático, não se justifica a instauração de lides penais temerárias, sem qualquer base probatória mínima, o que exige do Ministério Público a obtenção de elementos que se revelem capazes de informar, de modo idôneo e juridicamente apto a autoria e a materialidade dos fatos delituosos, em ordem a que a acusação criminal não se transforme, como já advertia o saudoso Ministro OROSIMBO NONATO, em "pura criação mental da acusação" (푸150/393).

Presentes tais considerações, não posso deixar de reconhecer a atuação responsável e independente do eminente Senhor Procurador-Geral da República, Dr. RODRIGO JANOT, que tem exercido a Chefia do Ministério Público da União com grande seriedade, atento aos gravíssimos encargos que incidem sobre o Ministério Público, notadamente em situações que envolvem implacável e necessária persecução estatal movida em face de delinquentes que, em contexto de criminalidade organizada, atentam contra o ordenamento positivo do Estado brasileiro, praticando delitos que têm ultrajado a consciência e desrespeitado o sentimento de decência do povo de nosso País.

Relembrando as lições de JOSÉ FREDERICO MARQUES, FRANCESCO CARNELUTTI, PIERO CALAMANDREI, entre tantos outros autores eminentes, não constitui demasia assinalar que regimes autocráticos, governantes ímprobos 
e cidadãos corruptos temem um Ministério Público independente, pois o Ministério Público, longe de curvar-se aos desígnios dos detentores do poder - tanto do poder político quanto do poder econômico superior percepção de que somente a preservação da ordem democrática e o respeito efetivo às leis da República revelam-se dignos de sua proteção institucional.

É preciso não desconsiderar nem desconhecer as lições da História, Senhora Presidente, e reconhecer que um Ministério Público independente e consciente de sua missão histórica e do papel institucional que lhe cabe desempenhar, sem tergiversações, no seio de uma sociedade aberta e democrática, constitui a certeza e a garantia da intangibilidade dos direitos dos cidadãos, da ampliação do espaço das liberdades fundamentais $\underline{e}$ do prevalecimento da supremacia do interesse social, especialmente em um País como o nosso, em que ainda lamentavelmente se evidenciam relações antagônicas e conflituosas, que tendem a patrimonializar a coisa pública, confundindo-a com a esfera privada de terceiros, ou que submetem pessoas indefesas ao arbítrio do Estado onipotente ou que expõem essa massa enorme de explorados $\underline{\mathbf{e}}$ despossuídos à avidez predatória daqueles que, criminosamente, desprezam, com insensível desrespeito às leis, à consciência moral, à solidariedade social e à Constituição, os valores básicos sobre os quais se funda qualquer sociedade digna, justa e fraterna.

Um Ministério Público forte e independente, consciente da alta responsabilidade institucional que the foi outorgada pela vontade soberana do Povo, reunido em Assembleia Nacional Constituinte: eis o significativo encargo que se atribuiu a essa notável instituição da República, pois - insista-se o Ministério Público representa o órgão especialmente incumbido, pela própria Constituição, de impedir que o abuso de poder, que a prepotência dos governantes, que o desrespeito às liberdades públicas, que a transgressão ao princípio da moralidade administrativa e que a ofensa aos postulados estruturadores do Estado Democrático de Direito culminem por gerar inadmissíveis retrocessos, incompatíveis com o espírito republicano e com a prática legítima do regime democrático.

3. O Supremo Tribunal Federal como garantidor dos direitos fundamentais dos cidadãos da República, inclusive daqueles que sofrem persecução penal

A referência que venho de fazer ao importantíssimo papel assumido pelo Ministério Público não significa, contudo, que o Poder Judiciário desconheça 
os direitos e garantias fundamentais titularizados por todos aqueles que sofrem persecução penal por parte do Estado, quaisquer que sejam os delitos a eles imputados.

Cumpre enfatizar, bem por isso, Senhora Presidente, que o Supremo Tribunal Federal garantirá, de modo pleno, às partes envolvidas nos litígios penais, na linha de sua longa e histórica tradição republicana, o direito a um julgamento justo, imparcial e independente com rigorosa observância de um dogma essencial ao sistema acusatório: 0 da paridade de armas, que impõe a necessária igualdade de tratamento entre o órgão da acusação estatal e aquele contra quem se promovem atos de persecução penal, em contexto que, legitimado pelos princípios estruturantes do Estado Democrático de Direito, repele a tentação autoritária de presumir-se provada qualquer acusação criminal e de tratar como se culpado fosse aquele em favor de quem milita a presunção constitucional de inocência.

Se assim efetivamente o é, Senhora Presidente, cabe também advertir que o Supremo Tribunal Federal, atento às anomalias que pervertem os fundamentos ético-jurídicos da República, repele, com vigor, os atos intoleráveis que buscam capturar, criminosamente, as instituições do Estado, submetendo-as, de modo ilegítimo, a pretensões inconfessáveis, em detrimento do interesse público.

Por tal razão, esta Corte Suprema não hesitará, agindo sempre com isenção e serenidade e respeitando os direitos e garantias fundamentais assegurados pela Constituição, em exercer nos termos da lei, o seu magistério punitivo, com a finalidade de restaurar a integridade da ordem jurídica violada, que não pode conviver com práticas desonestas de poder, pois todos sabemos $-\mathbf{e}$, no fundo, verdadeiramente sentimos - que nenhum cidadão poderá viver com dignidade em uma comunidade política corrompida, como destacou, em precisa observação, o eminente Professor CELSO LAFER.

Impende deixar assinalado neste ponto, por necessário, que a presunção constitucional de inocência não cessa nem deixa de prevalecer em face da instauração de investigação penal e/ou de processo criminal, inclusive naquelas hipóteses em que a revelação da suposta prática delitiva advém de depoimentos prestados por agentes colaboradores, pois - insista-se incide sobre o Ministério Público, no contexto do processo penal democrático, o ônus substancial de provar, para além de qualquer dúvida razoável, os fatos constitutivos da imputação penal, como tem reiteradamente acentuado a jurisprudência do Supremo Tribunal Federal: 


\section{AS ACUSAÇÕES PENAIS NÃO SE PRESUMEM PROVADAS: O ÔNUS} DA PROVA INCUMBE, EXCLUSIVAMENTE, A QUEM ACUSA.

- Nenhuma acusação penal presume-se provada. Não compete ao réu demonstrar a sua inocência. Cabe, ao contrário, ao Ministério Público comprovar de forma inequívoca, para além de qualquer dúvida razoável, a culpabilidade do acusado. Já não mais prevalece, em nosso sistema de direito positivo, a regra que, em dado momento histórico do processo político brasileiro (Estado Novo), criou, para o réu, com a falta de pudor que caracteriza os regimes autoritários, a obrigação de o acusado provar a sua própria inocência (Decreto-lei $n^{\circ}$ 88, de 20/12/37, art. 20,n. 5). Precedentes.

- Para o acusado exercer, em plenitude, a garantia do contraditório, tornase indispensável que o órgão da acusação descreva, de modo preciso os elementos estruturais ('essentialia delicti') que compõem o tipo penal, sob pena de devolver-se, ilegitimamente, ao réu o ônus (que sobre ele nãa incide) de provar que é inocente.

- Em matéria de responsabilidade penal, não se registra no modelo constitucional brasileiro qualquer possibilidade de o Judiciário, por simples presunção ou com fundamento em meras suspeitas, reconhecer a culpa do réu. Os princípios democráticos que informam o sistema jurídico nacional repelem qualquer ato estatal que transgrida o dogma de que não haverá culpa penal por presunção nem responsabilidade criminal por mera suspeita." (HC 88.875/AM, Rel. Min. CELSO DE MELLO)

4. O significado da "notitia criminis" e o dever estatal de investigar práticas delituosas, inclusive quando objeto de comunicação por potenciais agentes colaboradores

Cumpre reconhecer de outro lado, que se mostra legítima, em um contexto moralmente deteriorado de criminalidade organizada e de delinquência institucional (cujos autores buscam capturar as instituições do Estado, valendo-se, para tanto, de organizações criminosas altamente sofisticadas), a adoção por órgãos de persecução penal, de medidas de repressão contra essas gravíssimas práticas delituosas.

Isso significa, portanto, que o Ministério Público, sendo destinatário de comunicações ou de revelações de práticas criminosas, transmitidas, inclusive, por potenciais agentes colaboradores, não pode eximir-se de apurar 
a efetiva ocorrência de ilícitos penais, muitos dos quais caracterizadores $\underline{\mathrm{de}}$ uma preocupante macrodelinquência governamental.

É por essa razão, Senhora Presidente, que os atos de investigação ou de persecução no domínio penal traduzirão, em tal contexto, incontornável dever jurídico do Estado e constituirão por isso mesmo, resposta legítima do Poder

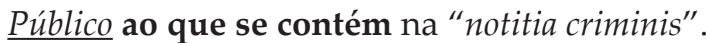

O significado e a importância da "notitia criminis" - cabe relembrar vêm ressaltados no magistério de eminentes doutrinadores, que nela vislumbram um expressivo meio justificador da instauração da investigação penal, pois, transmitido às autoridades públicas o conhecimento de suposta prática delituosa perseguível mediante ação penal pública incondicionada, a elas incumbe, por dever de ofício promover a concernente apuração da materialidade $\underline{\mathbf{e}}$ da autoria dos fatos e eventos alegadamente transgressores do ordenamento penal (JOSÉ FREDERICO MARQUES, "Elementos de Direito Processual Penal", vol. I/107-114, itens ns. 70-74, e vol. II/124, item n. 312, 3a atualização, 2009, Millennium; EDILSON MOUGENOT BONFIM, “Código de Processo Penal Anotado", p. 53/57, 3a ed., 2010, Saraiva; EUGÊNIO PACELLI DE OLIVEIRA, "Curso de Processo Penal", p. 39/42, item n. 4.1, 9a ed., 2008, Lumen Juris; DENILSON FEITOZA, "Direito Processual Penal - Teoria, Crítica e Práxis", p. 178, item n. 5.7, 6a ed., 2009, Impetus; RENATO BRASILEIRO DE LIMA, "Curso de Processo Penal", p. 92/93, item n. 8, 2013, Impetus; E. MAGALHÃES NORONHA, “Curso de Direito Processual Penal", p. 18/19, item n. 8, 19a ed., 1989, Saraiva; FERNANDO CAPEZ e RODRIGO COLNAGO, "Código de Processo Penal Comentado", p. 24, 2015, Saraiva; CARLOS FREDERICO COELHO NOGUEIRA, “Comentários ao Código de Processo Penal", vol. 1/187-193, itens ns. 55-58, 2002, Edipro; JULIO FABBRINI MIRABETE, "Processo Penal”, p. 64/68, item n. 3.3, 18 a ed., 2008, Atlas, v.g.).

$\underline{\mathrm{O}}$ aspecto que venho de ressaltar evidencia, portanto, o dever jurídico do

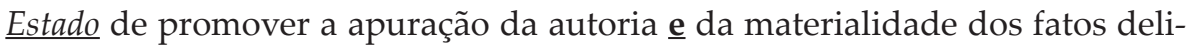
tuosos narrados por "qualquer pessoa do povo", inclusive aqueles eventos delatados por agentes colaboradores.

\section{O instituto da colaboração premiada: algumas considerações}

Nesse ponto, Senhora Presidente, assume inquestionável relevo o instituto da colaboração premiada. 
A colaboração premiada, embora em voga no direito processual penal italiano, notadamente a partir de meados da década de 1970, em contexto de combate ao terrorismo (que, em momento subsequente, no início da década de ' 90 , veio a ser utilizada na operação "Mãos Limpas", objetivando a repressão a práticas de corrupção governamental), surgiu, entre nós, no direito reinol, fundada nas Ordenações do Reino (1603), instituída, primariamente, com o objetivo de agraciar aqueles que delatassem os autores e partícipes do crime de falsificação de moeda (Título 116) e e sobretudo, do crime gravíssimo de "lesa-majestade" (Título 6), que constituía o mais sério delito previsto no temível Livro V do Código Filipino, o "liber terribilis", tal a prodigalidade com que esse estatuto legal cominava a pena de morte!!! Na Conjuração Mineira (1789), Joaquim Silvério dos Reis valeu-se desse meio e delatou os inconfidentes de Vila Rica, hoje Ouro Preto, havendo sido beneficiado pela legislação portuguesa consubstanciada, quanto a esse ponto, nas (então) vigentes Ordenações Filipinas!

O E. Superior Tribunal de Justiça, por sua vez, apoiando-se no precedente do Supremo Tribunal Federal firmado no julgamento do HC 127.483/PR, Rel. Min. DIAS TOFFOLI, bem definiu a natureza jurídica desse meio de obtenção de prova enfatizando que "A colaboração premiada é uma técnica especial de investigação, meio de obtenção de prova advindo de um negócio jurídico processual personalíssimo, que gera obrigações e direitos entre as partes celebrantes (Ministério Público e colaborador), não possuindo o condão de, por si só, interferir na esfera jurídica de terceiros, ainda que citados quando das declarações prestadas, faltando, pois, interesse dos delatados no questionamento quanto à validade do acordo de colaboração premiada celebrado por outrem [...]" (RHC 69.988/RL Rel. Min. REYNALDO SOARES DA FONSECA grifei).

Não se desconhece que o instituto da colaboração premiada, especialmente nos termos em que disciplinado pela Lei $\mathrm{n}^{\mathrm{o}}$ 12.850/2013 (arts. $4^{\circ}$ a $\left.7^{\circ}\right)$, vem sendo reconhecido por esta Suprema Corte, com apoio no magistério doutrinário (VALDOIR BERNARDI DE FARIAS, "Delação Premiada: constitucionalidade, aplicabilidade e valoração", p. 135/158, 153, "in" "Temas Contemporâneos de Direito", org. por José Carlos Kraemer Bortoloti e Luciane Drago Amaro, 2009, Méritos Editora, v.g.), que o qualifica como relevante instrumento de obtenção de prova, e não como meio de prova (HC 127.483/PR, Rel. Min. DIAS TOFFOLI, Pleno), $\underline{\text { refletindo }}$ em seu tratamento normativo, $\underline{\text { o que se }}$ delineou, no plano das relações internacionais, na Convenção de Palermo (Artigo 26) e na Convenção de Mérida (Artigo 37), ambas subscritas pelo Brasil e formalmente já incorporadas ao sistema de direito positivo interno de nosso 
País em virtude da promulgação, respectivamente, do Decreto no 5.015/2004 $\underline{\text { e }}$ do Decreto no $5.687 / 2006$.

Embora sofrendo críticas por parte de eminentes autores (CEZAR ROBERTO BITENCOURT PAULO CÉSAR BUSATO, “Comentários à Lei de Organização Criminosa", p. 115/117, item n. 1, 2014, Saraiva; RÔMULO DE ANDRADE MOREIRA, "A Delação no Direito Brasileiro", v.g.), o fato é que a Lei $\underline{n^{o} \mathbf{1 2 . 8 5 0 / 2 0 1 3}}$ " [...] traz aspectos positivos ao garantir ao delatado maior possibilidade de questionar o depoimento do delator, ao buscar diminuir a possibilidade de erro judiciário vedando-se condenação com fundamento exclusivo em delação, ao procurar garantir a integridade física do colaborador

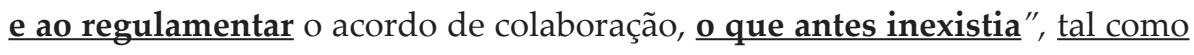
assinalam ROBERTO DELMANTO, ROBERTO DELMANTO JUNIOR $e$ FABIO M. DE ALMEIDA DELMANTO ("Leis Penais Especiais Comentadas", p. 1.003/1.051, 1.031, 2a ed., 2014, Saraiva - grifei), cuja lição, no entanto, ainda que reconhecendo a eficácia desse instituto "na apuração de gravíssimos crimes", não deixa de questionar-lhe os aspectos no plano ético.

A regulação legislativa do instituto da colaboração premiada importou em expressiva transformação do panorama penal vigente no Brasil, criando meios destinados a viabilizar e a forjar, juridicamente, um novo modelo de Justiça criminal que privilegia a ampliação do espaço de consenso e que valoriza, desse modo, na definição das controvérsias oriundas do ilícito criminal, a adoção de soluções fundadas na própria vontade dos sujeitos que compõem e integram a relação processual penal.

Esse aspecto que venho de referir mostra-se adequado a um modelo, iniciado na década de 1990, que claramente introduziu um novo paradigma de ustiça criminal, em que o elemento preponderante passa a ser o consenso dos protagonistas do próprio litígio penal.

Na realidade, a colaboração premiada ajusta-se, de certo modo, a esse novo paradigma que consagra, agora de maneira muito mais expressiva, considerado o marco normativo resultante da Lei $\mathrm{n}^{\mathrm{o}}$ 12.850/2013, um modelo de Justica consensual, em que prevalece, tendo em vista os benefícios de ordem premial acessíveis ao autor do fato delituoso, o princípio da autonomia de sua vontade.

Cabe assinalar, neste ponto, o caráter positivo da evolução jurisprudencial desta Corte a propósito do instituto em questão, eis que o Supremo Tribunal Federal, bem antes da Lei $n^{0}$ 12.850/2013 já admitia a utilização da colaboração premiada (cujo "nomen juris" anterior era o de delação premiada), ressalvando, no entanto, desde então, que nenhuma condenação penal 
poderia ter por único fundamento as declarações incriminadoras do agente

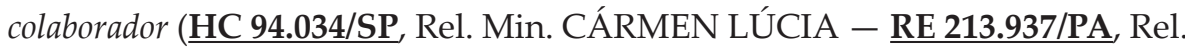
Min. ILMAR GALVÃO, v.g.):

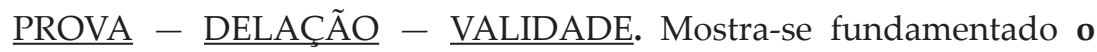
provimento judicial quando há referência a depoimentos que respaldam delação de corréus. Se de um lado, a delação de forma isolada, nãa respalda condenação, de outro, serve ao convencimento quando consentânea com as demais provas coligidas.

(HC 75.226/MS, Rel. Min. MARCO AURÉLIO - grifei)

A impossibilidade de condenação penal que tenha por suporte, unicamente, o depoimento prestado pelo agente colaborador, tal como acentua a doutrina (EDUARDO ARAÚJO DA SILVA, “Organizações Criminosas: aspectos penais e processuais da Lei $\mathbf{n}^{\mathbf{0}} \mathbf{1 2 . 8 5 0 / 1 3}$ ", p. 71/74, item n. 3.6, 2014, Atlas, v.g.), constitui importante limitação de ordem jurídica que, incidindo sobre os poderes do Estado, objetiva impedir que falsas imputações dirigidas a terceiros "sob pretexto de colaboração com a Justiça" possam provocar inaceitáveis erros judiciários, com injustas condenações de pessoas inocentes.

$\mathrm{Na}$ realidade o regime de colaboração premiada definido pela Lei $n^{\circ}$ 12.850/2013, estabelece mecanismos destinados a obstar abusos que possam ser cometidos por intermédio da ilícita utilização desse instituto, tanto que, além da expressa vedação já referida ("lex. cit.", art. 4ํㅗ \$16), o diploma legislativo em questão também pune como crime, com pena de 1 a 4 anos de prisão e multa, a conduta de quem imputa "falsamente, sob pretexto de colaboração com a Justiça, a prática de infração penal a pessoa que sabe ser inocente" ou daquele que revela "informações sobre a estrutura de organização criminosa que sabe inverídicas" (art. 19).

Com tais providências, o legislador brasileiro procurou neutralizar, em favor de quem sofre a imputação emanada de agente colaborador, os mesmos efeitos perversos da denunciação caluniosa revelados, na experiência italiana, pelo "Caso Enzo Tortora" (na década de 80), de que resultou clamoroso erro judiciário, porque se tratava de pessoa inocente, injustamente delatada por membros de uma organização criminosa napolitana ("Nuova Camorra Organizzata") que, a pretexto de cooperarem com a Justiça (e de, assim, obterem os benefícios legais correspondentes), falsamente incriminaram Enzo Tortora, então conhecido apresentador de programa de sucesso na RAI ("Portobello"). 
Mais do que isso, cumpre ter presente, ainda, a correta observação feita pelo saudoso e eminente Ministro TEORI ZAVASCKI no julgamento do HC 127.186/PR, de que foi Relator, ocasião em que expendeu considerações relevantes em torno do instituto da colaboração premiada, advertindo com absoluta

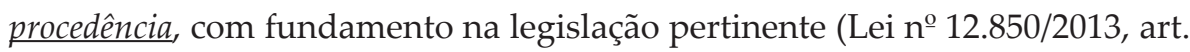
$4^{\circ}$, "caput" e $\left.\S 6^{\circ}\right)$, que "seria extrema arbitrariedade [...] manter a prisão preventiva [de alguém] como mecanismo para extrair do preso uma colaboração premiada, que, segundo a lei, deve ser voluntária" (grifei), concluindo com inteiro acerto, que "Subterfúgio dessa natureza, além de atentatório aos mais fundamentais direitos consagrados na Constituição, constituiria medida medievalesca que cobriria de vergonha qualquer sociedade civilizada" (grifei).

Registre-se, de outro lado, por necessário, que o Estado não poderá utilizar-se da denominada "corroboração recíproca ou cruzada", ou seja, não poderá impor condenação ao réu pelo fato de contra este existir, unicamente, depoimento de agente colaborador que tenha sido confirmado, tão somente, por outros delatores, valendo destacar, quanto a esse aspecto, a advertência do eminente Professor GUSTAVO BADARÓ ("O Valor Probatório da Delação Premiada: sobre o $\S 16$ do art. $4^{\circ}$ da Lei $n^{\circ} 12.850 / 2013^{\prime \prime}$ ):

A título de conclusão, podem ser formulados os seguintes enunciados:

A regra do $\$ 16$ do art. $4^{\circ}$ da Lei 12.850/13 aplica-se a todo e qualquer regime jurídico que preveja a delação premiada.

O $\$ 16$ do art. $4^{\circ}$ da Lei 12.850/13, ao não admitir a condenação baseada exclusivamente nas declarações do delator, implica uma limitação ao livre convencimento, como técnica de prova legal negativa.

É insuficiente para o fim de corroboração exigido pelo $\$ 16$ do art. $4^{\circ}$ da Lei 12.850/13 que o elemento de confirmação de uma delação premiada seja outra delação premiada, de um diverso delator, ainda que ambas tenham conteúdo concordante.

Caso o juiz fundamente uma condenação apenas com base em declarações do delator, terá sido contrariado o $\$ 16$ do art. $4^{\circ}$ da Lei 12.850/13 [...]." (grifei)

6. A natureza jurídica e os limites da homologação do acordo de colaboração premiada

Mostra-se relevante assinalar, de outro lado, que o magistrado, ao examinar o acordo de colaboração premiada, deve necessariamente fazê-lo, como 
determina a legislação, sob a tríplice perspectiva de sua voluntariedade, regularidade e legalidade (Lei $\mathbf{n}^{\mathbf{0}} \mathbf{1 2 . 8 5 0 / 2 0 1 3}$, art. $4^{\circ}, \S^{\circ}$ ), sendo certo que, ao proceder à homologação de referido pacto negocial, essencialmente fundado no consenso das partes envolvidas, exerce típica atividade de caráter jurisdicional, pois imprime a mencionado ajuste a própria autoridade de que se acha investido.

Importante relembrar por oportuno, decisão proferida pelo saudoso Ministro TEORI ZAVASCKI, na qual esse eminente magistrado, pronunciando-se sobre o alcance do ato de homologação do acordo de colaboração premiada, bem definiu os limites da supervisão judicial que deverão ser observados na formulação do concernente juízo delibatório:

[...] 5. Cumpre registrar que a decisão de homologação do termo de colaboração premiada faz juízo sobre sua "regularidade, legalidade e volun-

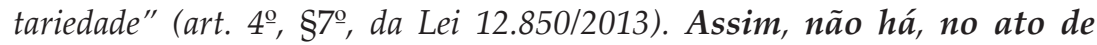
homologação, exame de fundo acerca do conteúdo dos depoimentos prestados, os quais só serão objeto de apreciação judicial no momento da sentença, em que as declarações prestadas serão valoradas em face das outras provas produzidas no processo. Nesse mesmo sentido: HC 127.483, Rel. Min. DIAS TOFFOLI, Tribunal Pleno, julgado em 27-8-2015. É na sentença, ademais, que o juiz examinará a própria eficácia de acordo, segundo expressamente estabelece a lei de regência (Lei 12.850/2013, art. 4, $\S 11)$.

(Pet 5.733/PR, Rel. Min. TEORI ZAVASCKI - grifei)

Vale mencionar, a propósito do que venho de referir, notadamente quanto à natureza e ao significado do ato de homologação, a sempre autorizada lição de CÂNDIDO RANGEL DINAMARCO ("Instituições de Direito Processual Civil", vol. III/272-274, item n. 936, 6a ed., 2009, Malheiros), para quem o magistrado, ao homologar o ato submetido à sua apreciação, "exerce atividade tipicamente estatal, caracterizada como jurisdição. É jurisdicional o ato homologatório em oposição ao caráter negocial do ato a ser homologado" (grifei).

Na realidade, o juiz competente efetua, em instância homologatória, avaliação que lhe permite promover "o controle das cláusulas abusivas, desproporcionais e ilegais" (LUIZ FLÁVIO GOMES e MARCELO RODRIGUES DA SILVA, "Organizações Criminosas e Técnicas Especiais de Investigação", p. 322, item n. 7.12.1, 2015, JusPODIVM), pautando-se, para esse efeito e de modo estrito, 
pelos critérios da voluntariedade, regularidade e legalidade, motivo pelo qual "Não deve o magistrado fazer outro juizo de valor que não estes elencados" (LUIZ FLÁVIO GOMES e MARCELO RODRIGUES DA SILVA, “op. loc. cit”).

Há portanto, considerados os vetores indicados na própria Lei nำ12.850/2013, efetivo controle jurisdicional sobre a legalidade das cláusulas estipuladas no acordo de colaboração premiada, cuja homologação, caso alguma dessas cláusulas mostre-se ilegal, deverá, então, ser recusada pelo juiz competente em razão de o acordo, nesse especifico ponto, achar-se em desarmonia com o texto da Constituição e com o sistema normativo.

Com esse procedimento, o magistrado competente (o Relator, nos Tribunais) dá concreção à cláusula que consagra, em respeito ao Parlamento (e, sobretudo, à Constituição da República), o princípio da legalidade.

Dessa maneira, a supervisão judicial das cláusulas mostrar-se-á sempre presente em relação a cada acordo de colaboração premiada, pois a fiscalização de legalidade pelo Poder Judiciário destina-se, precisamente, a impedir que se ajustem, no pacto negocial, cláusulas abusivas, ilegais ou desconformes ao ordenamento jurídico.

Dequalquermodo, ecomo resulta dalei - cujoteortemsidoincondicionalmente respeitado por esta Corte Suprema -, a concessão dos benefícios de caráter premial estará sempre condicionada à eficácia da cooperação do agente colaborador, pois, sem que o colaborador tenha cumprido todas as obrigações ajustadas, não terá ele acesso aos benefícios objeto do acordo de colaboração que tenha sido homologado.

Vê-se portanto, que os benefícios legais, de ordem penal e processual penal, ajustados no acordo de colaboração premiada objeto de regular homologação judicial somente serão suscetíveis de efetiva outorga se e quando o órgão judiciário competente, por ocasião do julgamento final da causa penal, constatar a partir do exame dos elementos de informação produzidos ao longo da instrução probatória, que o agente colaborador realmente cumpriu as obrigações que assumiu perante o Estado, tal como definidas no pacto negocial celebrado com o Ministério Público.

Idêntica percepção é revelada por MÁRCIO ADRIANO ANSELMO ("Colaboração Premiada - o Novo Paradigma do Processo Penal Brasileiro", p. 96, item n. 1.7, 2016, Mallet Editora), para quem "a apreciação judicial aprofundada [do acordo de colaboração premiada] somente se dá na sentença [...]", pelo fato de ser o julgamento final da causa penal - segundo adverte o magistério doutrinário (CLEBER MASSON e VINÍCIUS MARÇAL, "Crime Organizado", p. 169/173, item n. 4.1.8, 2ª ed., 2016, Método; RENATO BRASILEIRO DE LIMA, 
"Legislação Criminal Especial Comentada", p. 714/715, item n. 12.6, 5ำ ed., 2017, JusPODIVM; CARLA VERÍSSIMO DE CARLI, "Lavagem de Dinheiro", p. 234/235, item n. 2.1.2.6.6, 2ª ed., 2012, Verbo Jurídico, v.g.) - $\underline{\text { o momento }}$ procedimentalmente adequado em que o órgão judiciário competente deve analisar a eficácia objetiva da cooperação prestada pelo agente colaborador, eis que a concessão dos benefícios premiais previstos no acordo de colaboração premiada está necessariamente condicionada ao efetivo adimplemento das obrigações que tenham sido assumidas por referido colaborador $\underline{e}$ de cuja fiel execução advenha um ou mais dos resultados indicados no art. $4^{\circ}$, incisos I $\underline{\mathbf{a} \mathrm{V}}$, da Lei $\mathrm{n}^{0} \mathbf{1 2 . 8 5 0 / 2 0 1 3 .}$

É certo no entanto, que há autores (EDUARDO ARAUJO DA SILVA, "Crime Organizado - Procedimento Probatório", p. 83, item n. 4.1, 2003, Atlas; DAVID TEIXEIRA DE AZEVEDO, "A Colaboração Premiada num Direito Ético", "in" "Boletim do IBCCrim", no 83, p. 06, out/1999, v.g.) cuja lição - distinguindo entre efetividade da cooperação pessoal do agente colaborador de um lado, e eficácia na obtenção de resultados práticos em favor da persecução penal, de outro - sustenta que, havendo colaboração objetiva, mas não eficaz, a despeito da participação ativa e do empenho real do investigado ou do réu, tornar-se-á possível, mesmo assim, conceder-lhe, nos termos pactuados, os benefícios acordados.

7. A vinculação judicial aos benefícios de ordem premial objeto de regular homologação: uma imposição ético-jurídica fundada no postulado da segurança jurídica e no princípio da confiança

É importante deixar assinalado neste ponto, que o acordo de colaboração premiada, devidamente homologado, vincula o Poder Judiciário no julgamento final da causa penal, desde que as obrigações assumidas pelo agente colaborador tenham sido por este realmente cumpridas, pois - insista-se - é da efetiva execução das cláusulas ajustadas em referido pacto negocial que se viabilizará a concessão, ao agente colaborador, dos benefícios de ordem premial que por ele foram ajustados com o Estado.

De todo relevante destacar-se, em face da clareza de seu pensamento, a corretíssima lição de RENATO BRASILEIRO DE LIMA ("Legislação Criminal Especial Comentada", p. 714/715 e 734/736, itens ns. 12.6 e 12.11.3, 5a ed., 2017, JusPODIVM): 
Em todas as hipóteses acima citadas de colaboração premiada, para que o agente faça jus aos benefícios penais e processuais penais estipulados em cada um dos dispositivos legais, indispensável aferir a relevância e a eficácia objetiva das declarações prestadas pelo colaborador. Não basta a mera confissão acerca da prática delituosa. Em um crime de associação criminosa, por exemplo, a confissão do acusado deve vir acompanhada do fornecimento de informações que sejam objetivamente eficazes, capazes de contribuir para a identificação dos comparsas ou da trama delituosa.

Por força da colaboração, deve ter sido possível a obtenção de algum resultado prático positivo, resultado este que não teria sido alcançado sem as declarações do colaborador [...].

Comprovada a eficácia objetiva das informações prestadas pelo agente, a aplicação do prêmio legal inerente à respectiva colaboração premiada é medida que se impõe [...].

O magistrado não deve presenciar ou participar das negociações, enfim, não deve assumir um papel de protagonista das operações referentes ao acordo de colaboração premiada, sob pena de evidente violação do sistema acusatório (CF, art. 129, I) [...].

[...] o acordo deve ser submetido ao juiz para homologação, que não poderá deixar de observá-lo por ocasião da sentença, caso o colaborador tenha cumprido todas as obrigações previamente pactuadas. Considerando-se que, ao celebrar o acordo de colaboração premiada com o Ministério Público, o colaborador assume uma postura incomum para os criminosos, já que se afasta do próprio instinto de conservação (ou autoacobertamento), tanto individual quanto familiar, sujeito que fica a retaliações de toda ordem, haveria conduta desleal por parte do Estado-juiz se não the fosse concedida a sanção premial inerente à colaboração premiada, violando o próprio princípio da moralidade (CF, art. 37, 'caput'). Daí a importância da homologação pela autoridade judiciária, conferindo mais segurança ao acordo. Se o acordo de colaboração premiada funcionar como mera expectativa de direito para o colaborador, é natural que este não se sinta encorajado a 
experimentar todos os dissabores inerentes a sua traição, o que contribuiria para a redução da eficácia desse importante procedimento investigatório.

Desta decisão judicial que homologa o acordo de colaboração premiada não resultará, de imediato, a aplicação dos benefícios legais decorrentes do cumprimento do quanto pactuado. Afinal, pelo menos em regra, os benefícios legais decorrentes do cumprimento do acordo de colaboração premiada serão concedidos ao colaborador apenas por ocasião da prolação da sentença condenatória. Prova disso é o quanto disposto no art. $4^{\circ}, \S 11$, que prezê que a sentença apreciará os termos do acordo homologado e sua eficácia. Como se percebe, a homologação do acordo pelo juiz simplesmente confere ao colaborador maior segurança jurídica quanto à concessão do prêmio legal pactuado no momento da sentença, mas desde que as informações por ele prestadas sejam objetivamente eficazes para a consecução de um dos resultados elencados pelo legislador. (grifei)

Esse mesmo entendimento, por sua vez, que põe em destaque 0 caráter vinculante dos termos que compõem o acordo de colaboração premiada, desde que o agente colaborador tenha cumprido, integralmente, as cláusulas pactuadas em referido ajuste, é perfilhado por CLEBER MASSON e VINÍCIUS MARÇAL ("Crime Organizado", p. 182/184, item n. 4.1.8, 3르 ed., 2017, Método), como resulta de seu douto magistério:

[...] o acordo de colaboração premiada não tem vida própria, de maneira que, com a sua homologação judicial, ter-se-á apenas "uma promessa do juiz quanto à aplicação dos benefícios" oriundos do acordo formalizado, não garantindo "a fruição dos benefícios se colaboração prestada não for efetiva".

Em verdade, a eficácia do acordo ficará "condicionada à sentença final condenatória, sem a qual não poderia pensar na aplicação de redução, de substituição de qualquer pena, ou mesmo de perdão judicial". Portanto, somente ao término do processo penal, verificando-se que o crime se aperfeiçoou, e não sendo caso de absolvição (nada impede que o juiz absolva o colaborador), poderá o magistrado "premiar" o colaborador.

Com efeito, "a sentença apreciará os termos do acordo homologado e sua eficácia" (art. $4^{\circ}$, §11, da LCO). Uma vez homologado o acordo de colaboração premiada, o juiz em hipótese alguma poderá desconsiderar a avença. A lei é taxativa ao impor ao magistrado o dever de apreciar 
os termos do acordo e sua eficácia. Assim, o juiz deverá analisar se o colaborador efetivamente cumpriu o acordo de maneira a atingir um ou mais dos resultados grafados no 'caput' do art. $4^{\circ}$. Cumprido totalmente o acordo realizado, competirá ao magistrado aplicar o benefício proposto ao colaborador, sendo sensível à avença entabulada entre as partes e homologada em juizo.

Há, por assim dizer, uma vinculação judicial ao benefício acordado em caso de cumprimento integral da avença, pois, do contrário, "a noção de processo cooperativo restaria esvaziada e haveria um clima de indesejável insegurança jurídica na aplicação do instituto, pois o Ministério Público não teria como cumprir a sua obrigação no acordo, ante a possibilidade de o juiz não conceder o perdão judicial na sentença". O imprescindível controle judicial ocorrerá quando da homologação do acordo e de seu cumprimento, entretanto, "uma vez homologado e cumprido o acordo sem revogação ou retratação, não há como o juiz retratar-se na sentença".

Tal como decidido pelo Supremo Tribunal Federal, "os princípios da segurança jurídica e da proteção da confiança tornam indeclinável o dever estatal de honrar o compromisso assumido no acordo de colaboração, concedendo a sanção premial estipulada, legítima contraprestação ao adimplemento da obrigação por parte do colaborador.

Dessa maneira, é correto dizer que o juiz que homologou o acordo fica de certa forma vinculado aos seus termos, devendo conferir ao colaborador o benefício ajustado quando a colaboração tiver sido efetiva. (grifei)

É por essa razão que JOSÉ PAULO BALTAZAR JUNIOR ("Crimes Federais", p. 1.279, item n. 5.1.8.2, 10a ed., 2015, Saraiva), que exerceu com brilho a magistratura federal, examinando o tema pertinente à vinculação do juiz sentenciante ao conteúdo das cláusulas estabelecidas no acordo de colaboração premiada, adverte que o órgão judiciário competente, no julgamento final da causa penal, deverá respeitar o que houver sido pactuado em mencionado acordo, uma vez cumpridos, pelo agente colaborador, os termos ajustados em referido negócio jurídico:

Quer dizer, então, que o juiz, ao proferir a sentença, está vinculado ao acordo homologado, ressalvada a possibilidade de avaliação quanto 
à sua eficácia, com base nos dados apurados na instrução. Não é dado ao juiz, porém, na sentença, reavaliar a regularidade, voluntariedade e legalidade do acordo já levadas a efeito por ocasião da homologação do acordo. (grifei)

Também CIBELE BENEVIDES GUEDES DA FONSECA ("Colaboração Premiada", p. 119/123 e 125, item n. 3.5, 2017, Del Rey), ao discorrer sobre a questão, enfatiza que se impõe ao juiz, no momento no qual sentenciar a causa penal, respeitar, em plenitude, os termos pactuados no acordo de colaboração premiada, desde que o agente colaborador tenha cumprido as obrigações formalmente assumidas perante o Estado, não sendo lícito desse modo, ao órgão judiciário sentenciante desconsiderar, presente referido contexto, o que se estabeleceu no ajuste negocial:

Depois de fechados todos os detalhes do acordo, com as partes satisfeitas com as concessões e benefícios advindos da negociação, assina-se o Termo de Colaboração Premiada, peticionando-se ao Juiz competente para que o homologue.

Consoante o artigo $4^{\circ}$, $\S 6^{\circ}$, da nova lei de combate ao crime organizado, "O juiz não participará das negociações realizadas entre as partes para a formalização do acordo de colaboração". Prestigia-se, assim, o sistema acusatório, sem qualquer envolvimento por parte do juiz no acordo feito entre acusação e defesa.

A justiça negociada rompe essa tradição, relegando às partes, e tão somente a elas, as questões referentes ao acordo de colaboração premiada, restringindo-se o juiz ao papel de fiscal da legalidade e da voluntariedade do acordo. Essa reverência ao sistema acusatório encontra respaldo na Carta Magna, como já dito, além de inúmeros documentos internacionais, como por exemplo as Regras de Havana (Princípios Orientadores Relativos à Função dos Magistrados do Ministério Público), de 1990, adotadas no $8^{\circ}$ Congresso das Nações Unidas para a prevenção do Crime e Tratamento dos Delinquentes [...].

Desse modo, a tendência parece ser no sentido de que o juiz passe, efetivamente, a ter uma postura equidistante das partes também no processo penal, evitando qualquer participação na elaboração de acordo 
de colaboração premiada e restringindo sua atuação à fiscalização da legalidade e voluntariedade para fins de homologação da avença.

Se o acordo envolver alguma cláusula ilegal ou abusiva, ou for o caso de ausência de voluntariedade, dispõe o artigo $4^{\circ}, \S 8^{\circ}$, da citada lei que o juiz poderá recusar a homologação ou adequá-la ao caso concreto. Para Rogério Sanches Cunha e Ronaldo Batista Pinto, o juiz se submete ao princípio da discricionariedade regrada, de modo que, uma vez protocolado o acordo e preenchidos os requisitos objetivos e subjetivos, não resta alternativa ao julgador senão a homologação.

Ao final da instrução o juiz deverá proferir a sentença. Pergunta-se: poderá o juiz fugir do que ficou disposto no acordo homologado? Poderá o julgador aplicar pena diferente da combinada entre as partes? A resposta é negativa. Sendo o caso de justiça negociada, caberá ao juiz respeitar totalmente o que foi acordado [...]. (grifei)

Cumpre enfatizar, por extremamente relevante, que essa orientação doutrinária reflete-se, com absoluta fidelidade, no pensamento jurisprudencial desta Corte Suprema, como se pode ver do primoroso acórdão, da lavra do eminente Ministro DIAS TOFFOLI, proferido no julgamento plenário do HC 127.483/PR, no qual o Supremo Tribunal Federal - depois de reconhecer com inteiro acerto que é do Relator (e do Relator apenas) a competência para homologar, monocraticamente, o acordo de colaboração premiada, independentemente de ulterior referendo ou confirmação desse ato homologatório por parte de qualquer órgão colegiado deste Tribunal - assinalou, com inteira propriedade, que o cumprimento das obrigações assumidas pelo agente colaborador impede que o Poder Judiciário recuse-lhe a concessão $\underline{\text { dos }}$ benefícios de ordem premial, sob pena de o Estado-Juiz incidir em comportamento desleal, absolutamente inaceitável e de todo inadmissível, especialmente se se considerar a advertência feita por este próprio Supremo Tribunal Federal, que assim se pronunciou em referido julgado:

11. Os princípios da segurança jurídica $\underline{e}$ da proteção da confiança tornam indeclinável o dever estatal de honrar o compromisso assumido no acordo de colaboração, concedendo a sanção premial estipulada legítima contraprestação ao adimplemento da obrigação por parte do colaborador. (grifei) 
Cabe registrar, aqui, Senhora Presidente, por oportuno, uma observação que tenho por necessária.

Não se disse, nesta Corte, em momento algum, que o Supremo Tribunal Federal deve lealdade à Procuradoria-Geral da República, mas o que se destacou, isso sim, ao longo deste julgamento, com apoio em memorável acórdão unânime emanado do Plenário deste Tribunal, da lavra do eminente Ministro DIAS TOFFOLI, foi que o cumprimento das obrigações assumidas pelo agente colaborador atua como fator que impede o Poder Judiciário de negar, por ausência de causa legítima, ao colaborador os benefícios que com ele foram regularmente ajustados, sob pena de o Estado-Juiz transgredir $\underline{\text { o dever estatal }}$ de lealdade fundado no princípio da confiança.

E foi precisamente isso, Senhora Presidente, o que o Plenário do Supremo Tribunal Federal afirmou, de modo claro e inequívoco no precedente tantas vezes aqui referido:

[...] os princípios da segurança jurídica e da proteção da confiança tornam indeclinável o dever estatal de honrar o compromisso assumido no acordo de colaboração, concedendo a sanção premial estipulada, legítima contraprestação ao adimplemento da obrigação por parte do colaborador.

(HC 127.483/PR, Rel. Min. DIAS TOFFOLI - grifei)

O Plenário desta Corte Suprema, portanto, deixou assentado, sem qualquer dúvida, que o princípio da confiança e o postulado da segurança jurídica tornam inafastável o dever do Estado, representado por juízes e Tribunais, "de honrar o compromisso assumido no acordo de colaboração premiada" celebrado com o agente colaborador.

Insista-se pois, na seguinte asserção, que guarda inteira compatibilidade com a Constituição e as leis da República: o Supremo Tribunal Federal, a $\underline{\text { o }}$ honrar o acordo de colaboração premiada (para usar expressão textual constante do julgamento plenário do HC 127.483/PR), manifesta inteiro respeito ao ordenamento jurídico e pauta o seu comportamento pela estrita observância do princípio da legalidade.

Relembre-se, neste ponto, quanto ao aspecto ora referido, o magistério expendido por LUIZ FLÁVIO GOMES e MARCELO RODRIGUES DA SILVA ("Organizações Criminosas e Técnicas Especiais de Investigação: Questões Controvertidas, Aspectos Teóricos e Práticos e Análise da Lei 12.850/2013", p. 283/284, item n. 7.8.2, 2015, JusPODIVM): 
O acordo não pode gerar obrigações somente para o acusado colaborador. $O$ Estado também assume obrigações, e uma delas é justamente conceder os prêmios nos moldes do que foi pactuado e devidamente homologado pelo juiz. Não haveria sentido à homologação se não vinculasse o Poder Judiciário. Aliás, a homologação judicial tem a finalidade de garantir futuramente o cumprimento do acordo pelo Estado-juiz se alcançar os resultados.

O artigo 4", "caput", da Lei 12.850/13 reza que o juiz "poderá" conceder um dos prêmios lá previstos, fazendo transparecer que seria mera faculdade do juiz. Contudo, se o colaborador cumpriu todo o acordo tendo sua cooperação sido determinante no alcance dos resultados lá previstos, será um dever do magistrado conceder os prêmios.

O juiz está na realidade vinculado ao acordo celebrado se ele o homologou. Prova de que o juiz vincula-se ao acordo de colaboração premiada é a redação do artigo $4^{\circ}$, $1^{\circ}$, da Lei 12.850/13, que reza que "A sentença apreciará os termos do acordo homologado e sua eficácia". Vale dizer, o juiz apenas avaliará os resultados obtidos e os objetivos pretendidos, concedendo os prêmios na exata medida do que foi pactuado.

Claro que é na ocasião da sentença, após terminada a instrução e obtido o conjunto da prova, que o juiz poderá apurar com maior precisão o requisito da eficácia da colaboração, podendo, então, suprimir, total ou parcialmente, o benefício concedido, de forma justificada, caso, ao final, se comprove que a colaboração não foi eficaz. (grifei)

Disso tudo resulta, Senhora Presidente, ao contrário do que aqui se afirmou em voto que me precedeu, que a lealdade do Estado-Juiz, na matéria ora em exame, é somente devida à Constituição e ao ordenamento jurídico nela fundado.

Na realidade, os postulados da segurança jurídica, da boa-fé objetiva e da proteção da confiança, enquanto expressões do Estado Democrático de Direito, mostram-se impregnados de elevado conteúdo ético, social e jurídico, projetando-se sobre as relações jurídicas, mesmo as de direito público (RT) 191/922, Red. p/ o acórdão Min. GILMAR MENDES - MS 27.826-MC/DF Rel. Min. CELSO DE MELLO - MS 27.962-MC/DF, Rel. Min. CELSO DE MELLO, v.g.), tornando inderrogáveis as obrigações impostas ao Estado no contex to de acordos de colaboração premiada que o Poder Público tenha celebrado com agentes colaboradores. 
Não constitui demasia relembrar que o princípio da confiança e o postulado da segurança jurídica, enquanto expressões inerentes ao Estado Democrático de Direito, representam, como esta Corte já acentuou em julgados anteriores (RTI 192/620-621, Rel. Min. GILMAR MENDES, v.g.), “um componente de ética jurídica", cuja essencialidade tem sido reconhecida pelo magistério da doutrina (ALMIRO DO COUTO E SILVA, "Princípios da Legalidade e da Administração Pública e da Segurança Jurídica no Estado de Direito Contemporâneo", "in" RDP84/46-63;WEIDAZANCANER, "DaConvalidação e da Invalidação dos Atos Administrativos", p. 73/76, item n. 3.5.2, 3a ed., 2008, Malheiros; HELY LOPES MEIRELLES, "Direito Administrativo Brasileiro", p. 99/101, item n. 2.3.7, 34 a ed., atualizada por Eurico de Andrade Azevedo, Délcio Balestero Aleixo e José Emmanuel Burle Filho, 2008, Malheiros; CELSO ANTÔNIO BANDEIRA DE MELLO, "Curso de Direito Administrativo", p. 87 , item n. 77, e p. 123/125, item n. 27, 26 ed., 2009, Malheiros; MARIA SYLVIA ZANELLA DI PIETRO, "Direito Administrativo", p. 87/88, item n. 3.3.15.4, 22a ed., 2009, Atlas; MARÇAL JUSTEN FILHO, "Curso de Direito Administrativo", p. 1.097/1.100, itens ns. XVII.1 a XVII.3.1, 4a ed., 2009, Saraiva; GUSTAVO BINENBOJM, "Temas de Direito Administrativo e Constitucional", p. 735/740, itens ns. II.2.2 a II.2.2.2, 2008, Renovar; RAQUEL MELO URBANO DE CARVALHO, "Curso de Direito Administrativo", p. 78/94, itens ns. 8 a 8.4, 2008, Podivm; LÚCIA VALLE FIGUEIREDO, "Curso de Direito Administrativo", p. 257/260, itens ns. 3.2 a 4, 9 ed., 2008, Malheiros; MATEUS EDUARDO SIQUEIRA NUNES BERTONCINI, "Princípios de Direito Administrativo Brasileiro", p. 178/180, item n. 4.5.7, 2002, Malheiros; SÉRGIO FERRAZ, "O princípio da segurança jurídica em face das reformas constitucionais", "in" Revista Forense, vol. 334/191-210; RICARDO LOBO TORRES, "A Segurança Jurídica e as Limitações Constitucionais ao Poder de Tributar", p. 429/445, "in" "Princípios e Limites da Tributação", coordenação de Roberto Ferraz, 2005, Quartier Latin, v.g.).

É importante referir, neste ponto, em face de sua extrema pertinência, $\underline{\text { a }}$ aguda observação de J. J. GOMES CANOTILHO ("Direito Constitucional e Teoria da Constituição", p. 250, 1998, Almedina):

Estes dois princípios - segurança jurídica e proteção da confiança andam estreitamente associados a ponto de alguns autores considerarem o princípio da proteção de confiança como um subprincípio ou como uma dimensão específica da segurança jurídica. Em geral, considera-se que a segurança jurídica está conexionada 
com elementos objetivos da ordem jurídica - garantia de estabilidade jurídica, segurança de orientação e realização do direito - enquanto a protecção da confiança se prende mais com as componentes subjetivas da segurança, designadamente a calculabilidade e previsibilidade dos indivíduos em relação aos efeitos jurídicos dos atos dos poderes públicos. A segurança e a proteção da confiança exigem, no fundo: (1) fiabilidade, clareza, racionalidade e transparência dos atos do poder; (2) de forma que em relação a eles o cidadão veja garantida a segurança nas suas disposições pessoais e nos efeitos jurídicos dos seus próprios atos. Deduz-se já que os postulados da segurança jurídica e da proteção da confiança são exigíveis perante "qualquer ato" de "qualquer poder" - legislativo, executivo $\underline{e}$ judicial. (grifei)

Todas essas lições, portanto, Senhora Presidente, ministradas pela doutrina e observadas pela jurisprudência dos Tribunais, inclusive por esta Corte Suprema, tornam imperativo que o Estado-Juiz respeite as cláusulas pactuadas no acordo de colaboração premiada regularmente homologado e conceda ao agente colaborador os benefícios premiais ajustados em referido negócio jurídico, quando eficaz a sua cooperação no atingimento dos resultados práticos perseguidos pelo Estado em matéria de repressão à criminalidade organizada.

8. O acordo de colaboração premiada, desde que regularmente homologado por órgão judiciário competente, configura ato jurídico perfeito do qual resulta, quando adimplido pelo agente colaborador $\underline{\text { direito subjetivo que lhe garante acesso }}$ aos benefícios de ordem legal

É importante assinalar que o acordo de colaboração premiada regularmente homologado, qualquer que tenha sido a instância perante a qual celebrado, qualifica-se como ato jurídico perfeito revelando-se insuscetível de modificação, ressalvadas as hipóteses de seu descumprimento por parte do agente colaborador ou da superveniência de causa legítima apta a desconstituí-lo.

Isso significa que o acordo de colaboração premiada, uma vez judicialmente homologado, expõe-se à incidência do postulado inscrito no art. 5o, inciso XXXVI, da Carta Política, cuja vocação protetiva tem por objetivo resguardar a incolumidade de situações definitivamente consolidadas, exceto se ocorrente qualquer das hipóteses anteriormente referidas. 
Por traduzir típico ato jurídico perfeito o acordo de colaboração premiada - desde que homologado na forma do $\$ 7^{\circ}$ do art. $4^{\circ}$ da Lei $\mathrm{n}^{\mathrm{0}}$ 12.850/2013 - deverá ser respeitado por todos os órgãos e agentes do Estado, sob pena de imprestabilização desse importante meio de obtenção de prova, eis que entendimento diverso, que admitisse a desconsideração de referido pacto negocial, faria instaurar situação de total instabilidade $\mathbf{e} \underline{\mathrm{de}}$ completa insegurança jurídica, fatores que culminariam por desestimular a celebração de tais acordos por potenciais agentes colaboradores.

Presente essa configuração do acordo de colaboração premiada homologado por órgão judiciário competente, circunstância que o torna subsumível - insista-se - à noção de ato jurídico perfeito, passa ele a reger as relações jurídicas entre o Estado e o agente colaborador, produzindo como resultado que the é conatural, importantes consequências no plano do Direito, que se acham protegidas pela norma de salvaguarda consubstanciada no art. $5^{\circ}$, inciso XXXVI, da Constituição da República, como ordinariamente ocorre com simples contratos de direito privado (RTI

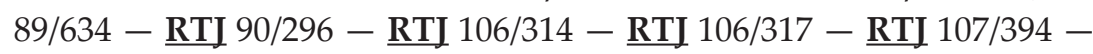
RTJ 112/759, v.g.), ressalvadas, como já destacado, as situações excepcionais anteriormente mencionadas (inadimplemento pelo agente colaborador, das obrigações pactuadas e/ou superveniência de causa legitimadora da invalidação do acordo de colaboração premiada).

Em suma: o acordo de colaboração premiada legitimamente celebrado, objeto de regular homologação judicial, apresenta-se revestido de força vinculante quanto a suas cláusulas, independentemente da instância (ou da esfera de Poder) em que pactuado, impondo-se, quanto à sua execução, por efeito do ajuste de vontades, à observância dos Poderes do Estado, notadamente do Judiciário, e do agente colaborador, que deverão cumpri-lo, obrigados que se acham a respeitá-lo em razão dos princípios da probidade e da boa-fé ("pacta sunt servanda").

9. Ilegitimidade ativa de terceiros para efeito de impugnação do acordo de colaboração premiada

Vale também recordar que a jurisprudência plenária desta Suprema Corte firmou-se no sentido de recusar em favor de terceiros, legitimidade ativa "ad causam" para questionar - por meio de "habeas corpus" (ou de qualquer outra ação judicial, exceto no âmbito de procedimento penal instaurado contra o delatado e no qual este figure como investigado ou como réu) - $\underline{\text { a validade }}$ 
jurídica do ato que homologou acordo de colaboração premiada celebrado entre $o$ Ministério Público e agentes colaboradores, eis que o negócio jurídico processual em questão, em razão de sua natureza personalíssima, constitui, em relação a terceiros, "res inter alios acta", a significar que o seu conteúdo não obriga nem vincula a esfera jurídica dos "extranei", motivo pelo qual nem mesmo os corréus (ou partícipes) dos crimes praticados pelo colaborador, eventualmente mencionados nas declarações subjacentes ao acordo, adquirem legitimação jurídica para buscar-lhe a invalidação, com a única ressalva destacada no item $\underline{\text { n. } 7}$ da ementa plenária a seguir reproduzida:

"Habeas corpus". [...] Acordo de colaboração premiada. Homologação judicial (art. $4^{\circ}, \S^{\circ}$, da Lei $n^{\circ}$ 12.850/13). Competência do relator (art. 21, I e II, do Regimento Interno do Supremo Tribunal Federal). Decisão que, no exercício de atividade de delibação, se limita a aferir a regularidade, a voluntariedade e a legalidade do acordo. Ausência de emissão de qualquer juízo de valor sobre as declarações do colaborador. Negócio jurídico processual personalíssimo. Impugnação por coautores ou partícipes do colaborador. Inadmissibilidade. Possibilidade de, em juízo, os partícipes ou os coautores confrontarem as declarações do colaborador e de impugnarem, a qualquer tempo, medidas restritivas de direitos fundamentais adotadas em seu desfavor. [...].

5. A homologação judicial do acordo de colaboração, por consistir em

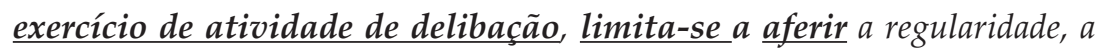
voluntariedade e a legalidade do acordo, não havendo qualquer juízo de valor a respeito das declarações do colaborador.

6. Por se tratar de negócio jurídico personalíssimo, o acordo de colaboração premiada não pode ser impugnado por coautores ou partícipes do colaborador na organização criminosa e nas infrações penais por ela praticadas, ainda que venham a ser expressamente nominados no respectivo instrumento no "relato da colaboração e seus possíveis resultados" (art. 6으, I, da Lei $n^{\circ}$ 12.850/13).

7. De todo modo nos procedimentos em que figurarem como imputados, os coautores ou partícipes delatados - no exercício do contraditório - poderão confrontar em juizo, as declarações do colaborador e as provas por ele indicadas, bem como impugnar, a qualquer tempo, as medidas restritivas de direitos fundamentais eventualmente adotadas em seu desfavor. [...].

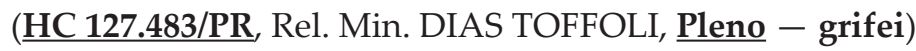


Esse mesmo entendimento tem sido reafirmado por esta Suprema Corte em sucessivos julgamentos colegiados (Pet 5.885-AgR/DF, Rel. Min. TEORI

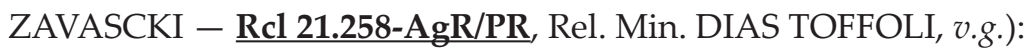

[...] 4. A eventual desconstituição de acordo de colaboração premiada tem âmbitode eficácia restrito às partes que ofirmaram, não beneficiando nem prejudicando terceiros (HC 127.483, Rel. Min. DIAS TOFFOLI, Tribunal Pleno, DJe de 4.2.2016). Até mesmo em caso de revogação do acordo o material probatório colhido em decorrência dele pode ainda assim ser utilizado em face de terceiros, razão pela qual não ostentam eles, em princípio, interesse jurídico em pleitear sua desconstituição, sem prejuizo, obviamente, de formular, no momento próprio, as contestações que entenderem cabíveis quanto ao seu conteúdo. Precedentes.

(Inq 3.979/DF Rel. Min. TEORI ZAVASCKI - grifei)

10. A defesa do delatado e a possibilidade de acesso notadamente o de seu Advogado ao depoimento do agente colaborador e às provas resultantes de tal declaração

A ausência de legitimidade ativa de terceiros para impugnar o próprio acordo de colaboração premiada, tal como anteriormente assinalado, não significa, contudo, que aquele que vier a ser delatado não possa proteger-se em face das consequências eventualmente lesivas resultantes de referido acordo.

Esta Corte Suprema, no julgamento plenário a que anteriormente aludi (HC 127.483/PR Rel. Min. DIAS TOFFOLI), reconheceu a possibilidade de o delatado contestar em juízo, no exercício do direito de defesa, o depoimento do agente colaborador $\underline{\mathbf{e}}$ as provas que se produzirem por efeito de sua cooperação, podendo impugnar, ainda, sempre no procedimento penal-persecutório em que ostentar a condição de investigado, indiciado ou réu, as medidas de privação de sua liberdade ou de restrição a seus direitos.

Esse entendimento foi corretamente perfilhado pela eminente Professora e Procuradora da República Dra. CIBELE BENEVIDES GUEDES DA FONSECA em valiosa monografia que escreveu sobre a matéria ora em exame ("Colaboração Premiada", p. 179 e 183, 2017, Del Rey), na qual, ao tratar do tema referente aos direitos e garantias do delatado, expendeu considerações de que reproduzo o seguinte fragmento: 
A pessoa mencionada em acordo de colaboração premiada ostenta, por óbvio, todos os direitos e garantias conferidos pela Constituição Federal de 1988 aos investigados e acusados em geral: tem o direito de conhecer as provas contra si produzidas, bem como se defender dos atos que lhe forem atribuídos, tudo em conformidade com os princípios da presunção da não culpabilidade, contraditório, ampla defesa e devido processo legal.

Ao depender das investigações, a pessoa delatada poderá ser denunciada, passando a figurar como acusada, quando então the são conferidas todas as garantias plenas do devido processo legal, contraditório e ampla defesa. Assim, após o recebimento da denúncia o delatado tem amplo direito de conhecer o processo penal em trâmite, em sua integralidade, o que inclui a identidade e as menções feitas pelo réu colaborador.

Assim, ao acessar os depoimentos do réu colaborador, a pessoa ali mencionada poderá aquilatar a gravidade das afirmações contra si levantadas, inclusive a firmeza e a convicção por parte do cooperante, $\underline{\text { bem }}$ como os meios de prova que o colaborador indica como corroboração ao que alega. No mais, a pessoa delatada tem amplo direito ao contraditório e ampla defesa, podendo refutar todas as afirmações do colaborador." (grifei)

Inquestionável em referido contexto, a possibilidade de o delatado (investigado ou réu), por intermédio de seu Advogado, ter conhecimento e acesso aos elementos de informação, inclusive ao depoimento $\underline{\text { do agente }}$ colaborador especialmente em face da própria jurisprudência firmada pelo Supremo Tribunal Federal:

RECLAMAÇÃO. DESRESPEITO AO ENUNCIADO CONSTANTE DA SÚMULA VINCULANTE № 14/STF. PERSECUÇÃO PENAL AINDA NA FASE DE INVESTIGAÇÃO POLICIAL. REGIME DE SIGILO. INOPONIBILIDADE AO ADVOGADO CONSTITUÍDO PELO INDICIADO OU PELO RÉU. DIREITO DE DEFESA. COMPREENSÃO GLOBAL DA FUNÇÃO DEFENSIVA. GARANTIA CONSTITUCIONAL. PRERROGATIVA PROFISSIONAL DO ADVOGADO (LEI № 8.906/94, ART. $7^{\circ}$, INCISOS XIII E XIV). CONSEQUENTE ACESSO AOS ELEMENTOS PROBATÓRIOS 
IÁ DOCUMENTADOS, PRODUZIDOS E FORMALMENTE INCORPORADOS AOS AUTOS DA PERSECUÇÃO PENAL (INQUÉRITO POLICIAL OU PROCESSO JUDICIAL) OU A ESTES REGULARMENTE APENSADOS. POSTULADO DA COMUNHÃO OUDA AQUISIÇÃO DA PROVA. PRECEDENTES (STF). DOUTRINA. MEDIDA CAUTELAR DEFERIDA.

- O sistema normativo brasileiro assegura ao Advogado regularmente constituído pelo indiciado (ou pelo réu) o direito de pleno acesso aos autos de persecução penal, mesmo que sujeita em juízo ou fora dele, a regime de sigilo (necessariamente excepcional), limitando-se, no entanto, tal prerrogativa jurídica às provas já produzidas e formalmente incorporadas ao procedimento investigatório, excluídas, consequentemente, as informações e providências investigatórias ainda em curso de execução e, por isso mesmo,

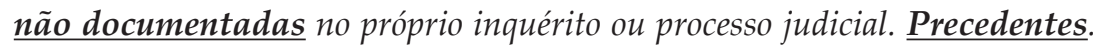
Doutrina.

(Rcl 18.399-MC/SP, Rel. Min. CELSO DE MELLO)

Não se pode desconhecer, considerado o modelo constitucional vigente em nosso País, que qualquer pessoa sujeita a medidas de investigação penal qualifica-se como sujeito de direitos, dispondo, nessa condição, mesmo na fase pré-processual, de garantias plenamente oponíveis ao poder do Estado (RT) 168/896-897, Rel. Min. CELSO DE MELLO, v.g.), pois - não constitui demasia reafirmá-lo - "A unilateralidade da investigação penal não autoriza que se desrespeitem as garantias básicas de que se acha investido, mesmo na fase pré-processual, aquele que sofre, por parte do Estado, atos de persecução criminal" (RTJ 200/300, Rel. Min. CELSO DE MELLO).

É sempre importante relembrar que essa prerrogativa da pessoa sob investigação também encontra fundamento no postulado da comunhão da prova, cuja eficácia projeta-se e incide sobre todos os dados informativos que, concernentes à "informatio delicti", compõem o acervo probatório coligido pelas autoridades e agentes estatais.

Esse postulado assume inegável importância no plano das garantias de ordem jurídica reconhecidas ao investigado e ao réu, pois, como se sabe, o princípio da comunhão (ou da aquisição) da prova assegura ao que sofre persecução penal - ainda que submetida esta ao regime de sigilo - o direito de conhecer os elementos de informação já existentes nos autos e cujo teor possa ser eventualmente, de seu interesse, quer para efeito de exercício da autodefesa, quer para desempenho da defesa técnica. 
É que a prova penal uma vez regularmente introduzida no procedimento persecutório, não pertence a ninguém, mas integra os autos do respectivo inquérito ou processo, constituindo desse modo, acervo plenamente acessível a todos quantos sofram, em referido procedimento sigiloso, atos de persecução penal por parte do Estado.

Essa compreensão do tema - cabe ressaltar - é revelada por autorizado magistério doutrinário (ADALBERTO JOSÉ Q. T. DE CAMARGO ARANHA, "Da Prova no Processo Penal", p. 31, item n. 3, 3a ed., 1994, Saraiva; DANIEL AMORIM ASSUMPÇÃO NEVES, "O Princípio da Comunhão da Prova", "in" Revista Dialética de Direito Processual (RDDP), vol. 31/19-33, 2005; FERNANDO CAPEZ, “Curso de Processo Penal”, p. 259, item n. 17.7, 7a ed., 2001, Saraiva; MARCELLUS POLASTRI LIMA, “A Prova Penal”, p. 31, item n. 2, 2a ed., 2003, Lumen Juris, v.g.), valendo referir por extremamente relevante, a_ lição expendida por JOSÉ CARLOS BARBOSA MOREIRA ("O Juiz e a Prova", "in" Revista de Processo, nº 35, Ano IX, abril/junho de 1984, p. 178/184):

E basta pensar no seguinte: $\underline{\text { se a prova for feita, pouco importa a sua }}$ origem. [...]. A prova do fato não aumenta nem diminui de valor segundo haja sido trazida por aquele a quem cabia o ônus, ou pelo adversário. A isso se chama o 'princípio da comunhão da prova': a prova depois de feita comum, não pertence a quem a faz, pertence ao processo; pouco importa sua fonte, pouco importa sua proveniência. [...]. (grifei)

Cumpre rememorar ainda, ante a sua inteira pertinência, o magistério de PAULO RANGEL ("Direito Processual Penal”, p. 411/412, item n. 7.5.1, 8 ed., 2004, Lumen Juris):

A palavra comunhão vem do latim 'communione', que significa ato ou efeito de comungar, participação em comum em crenças, ideias ou interesses. $\underline{\text { Referindo-se à prova, portanto, quer-se dizer que a mesma, uma vez no }}$ processo, pertence a todos os sujeitos processuais (partes e juiz), não obstante ter sido levada apenas por um deles. [...].

O princípio da comunhão da prova é um consectário lógico dos princípios da verdade real e da igualdade das partes na relação jurídico-processual, pois as partes, a fim de estabelecer a verdade histórica nos autos do processo, não abrem mão do meio de prova levado para os autos. 
[...] Por conclusão, os princípios da verdade real e da igualdade das partes na relação jurídico-processual fazem com que as provas carreadas para os autos pertençam a todos os sujeitos processuais, ou seja, dão origem ao princípio da comunhão das provas. (grifei)

É por tal razão que se impõe assegurar ao Advogado, em nome de seu constituinte, $\mathbf{o}$ acesso a toda informação já produzida e formalmente incorporada aos autos da investigação penal em causa, mesmo porque o conhecimento do acervo probatório pode revestir-se de particular relevo para a própria elaboração da defesa técnica por parte do interessado.

É fundamental no entanto, que os elementos probatórios já tenham sido formalmente produzidos nos autos da persecução penal.

O que não se revela constitucionalmente lícito segundo entendo, é impedir que o interessado, qualquer interessado, tenha pleno acesso aos dados probatórios que, já documentados nos autos (porque a estes formalmente incorporados ou a eles regularmente apensados), veiculam informações que possam revelar-se úteis ao conhecimento da verdade real e à condução da defesa da pessoa investigada ou processada pelo Estado, ainda que o procedimento de persecução penal esteja submetido a regime de sigilo.

O fato irrecusável no exame da questão do acesso a procedimentos estatais em regime de sigilo - especialmente naqueles casos em que o Estado vale-se do instituto da colaboração premiada - é um só: o delatado - como assinala a doutrina (FREDERICO VALDEZ PEREIRA, "Delação Premiada legitimidade e procedimento", p. 124/125, item n. 4.2.3.1, 2013, Juruá) - tem, constitucionalmente, o direito de confrontar, em sede processual, o colaborador ou delator, em razão da prerrogativa do contraditório, assegurada, em juízo, a quem sofre imputação penal deduzida pelo Estado.

\section{Conclusão}

Sendo assim e em face das razões expostas, peço vênia para negar provimento ao recurso de agravo e para acompanhar o eminente Relator na resolução da questão de ordem.

É o meu voto. 